\title{
FIRST RECORD OF THE CHINESE FANRAY, PLATYRHINA SINENSIS (ELASMOBRANCHII: MYLIOBATIFORMES: PLATYRHINIDAE), IN THE SEAWATERS OF ZHUJIAJIAN, ZHOUSHAN, CHINA
}

\author{
Zhi CHEN ${ }^{1}$, Xiaoyan WANG ${ }^{2}$, Jie ZHANG ${ }^{3}$, Yuan LI ${ }^{4}$, Tianxiang GAO ${ }^{2,5^{*}}$, and Longshan LIN ${ }^{* *}$ \\ ${ }^{1}$ Institute of Evolution and Marine Biodiversity, Ocean University of China, Qingdao, China \\ ${ }^{2}$ National Engineering Research Center for Marine Aquaculture, Zhejiang Ocean University, Zhoushan, China \\ ${ }^{3}$ Key Laboratory of Zoological Evolution and Systematics, Institute of Zoology, Chinese Academy of Sciences, \\ Beijing, China \\ ${ }^{4}$ Third Institute of Oceanography, State Oceanic Administration, Xiamen, China \\ ${ }^{5}$ Key Laboratory of Sustainable Utilization of Technology Research for Fishery Resource of Zhejiang Province, \\ Zhoushan, China
}

\begin{abstract}
Chen Z., Wang X., Zhang J., Li Y., Gao T., Lin L. 2018. First record of the Chinese fanray, Platyrhina sinensis (Elasmobranchii: Myliobatiformes: Platyrhinidae), in the seawaters of Zhujiajian, Zhoushan, China. Acta Ichthyol. Piscat. 48 (4): 409-414.
\end{abstract}

\begin{abstract}
There are several studies of the ichthyofauna of the East China Sea, however, the knowledge of fishes from this region still remains incomplete. This report confirms the occurrence of Chinese fanray, Platyrhina sinensis (Bloch et Schneider, 1801), in the seawaters of Zhoushan by analysing nine specimens of the Chinese fanray obtained in Zhujiajian from May 2017 to December 2017. The morphometric measurements and meristic counts were taken. The principal characters that are conclusive for the species were consistent with $P$. sinensis and were sufficient for separation of the examined specimens from other Platyrhina species. In addition, the fragment of 12S rRNA was also sequenced for the purpose of classification. The mean genetic distance within $P$. sinensis group was $0.71 \%$, group mean distance between $P$. sinensis and other Platyrhina species ranged from $6.01 \%$ to $7.71 \%$. Species were also separated from each other at the genetic level. Given the Chinese fanray has not been reported to exist in this region, our findings represent the first record from Zhoushan and extend the distribution range of this species into the north of the East China Sea. The reason behind the observed northward migration of some $P$. sinensis individuals from their southern habitat might be global warming. Collection of many additional specimens is needed to better define the geographic limits of the Chinese fanray.
\end{abstract}

Keywords: Platyrhina sinensis, seawaters of Zhoushan, first record, 12S rRNA, global warming, zoogeography, fish taxonomy

\section{INTRODUCTION}

The marine fish fauna of the East China Sea is characterized by considerable species richness and diversity (Zhao et al. 2012, 2016), and have a significant place in Chinese ichthyology due to the presence of numerous endemic species with restricted distribution ranges. The fish fauna checklist of Zhu and Meng (2001) on the East China Sea includes 647 species, but now the marine fish species of the area lists contains as many as 732 species (Zhao et al. 2016). The increased number of species is a consequence of several factors, such as the introduction of exotic species, range extension of the species, and identification of new species (Zhao et al. 2012, 2016).

It is difficult, however, to make new findings for rare and economically insignificant species such as rays, which have always been overlooked. The Chinese fanray, Platyrhina sinensis (Bloch et Schneider, 1801), is a benthic ray (Bloch and Schneider 1801) occurring from the south of China to Vietnam (Zhang et al. 1955, Chu 1960, Chen et al. 1997, Chu and Wu 1984, Iwatsuki et al. 2011). The knowledge of the distribution of Chinese fanray is still insufficient to define their potential distributional range. In particular, data on their distribution in the East China 
Sea are still lacking, even though this sea is closest to the south of China. Apart from the Taiwan Strait and the South China Sea, specimens of "P. sinensis" has been recorded in other areas including the East China Sea, however, these records in China were the misidentification of Platyrhina tangi Iwatsuki, Zhang et Nakaya, 2011 as P. sinensis (see Tang 1933, Compagno et al. 1999, 2005, Nakabo 2002, Iwatsuki et al. 2011, Zhao et al. 2012, 2016).

\section{MATERIAL AND METHODS}

From May 2017 to December 2017, nine samples of Platyrhina sinensis were collected in the seawaters of Zhujiajian $\left(122^{\circ} 25.109^{\prime} \mathrm{E}, 2^{\circ} 52.551^{\prime} \mathrm{N}\right)$, Zhoushan. Therefore, this paper is the first reliable report from this area and extends the distribution range of the Chinese fanray into the north of the East China Sea.

In order to better preserve the original morphology of the presently reported $P$. sinensis samples, we kept specimens in a freezer prior to examination. The body colour and pigmentation of specimens were pictured, together with all counts and measurements handled. All collected specimens were identified based on morphological characteristics used by Tang (1933), Last et al. (2006), Iwatsuki et al. (2011), and White and Last (2016). The majority of the measurements followed the existing convention for rays and sharks and were taken directly (point to point) unless otherwise stated. Detailed guidance of counts and measurements was listed as follows: total length (TL); snout length (defined as direct length from the snout tip to the firm nasal capsule adjacent the orbit-forward of eye socket); spiracle length (greatest length of the main cavity); pre-oral length (direct length from the snout to the posterior edge of upper jaw at its symphysis); mouth width (taken across the exposed width); pelvic fin insertion to dorsal fin origin-horizontal distance from the pelvic insertion to the origin of the first dorsal fin.

In addition to the morphological study, a DNA barcoding approach was also employed to support the taxon of $P$. sinensis at the genetic level. For genetic study, a piece of muscle tissue was obtained to carry out DNA extraction. The classical phenol-chloroform method was used for DNA extraction. PCR was subsequently conducted. The sequences of MiFish-E-F and MiFish-E-R primers used for 12S rRNA amplification were 5'-GTTGGTAAATCTCGTGCCAGC-3' and 5'-CATAGTGGgGtATCTAATCCTAGTTTG-3' (Miya et al. 2015), respectively. PCR was carried out in a 25 $\mu \mathrm{L}$ reaction mix containing DNA template $(1 \mu \mathrm{L}, 50$ $\left.\mathrm{ng} \cdot \mathrm{uL}^{-1}\right)$, forward primer $\left(1 \mu \mathrm{L}, 10 \mathrm{uM} \cdot \mathrm{L}^{-1}\right)$, reverse primer $\left(1 \mu \mathrm{L}, 10 \mathrm{uM} \cdot \mathrm{L}^{-1}\right)$, dNTPs $\left(2 \mu \mathrm{L}, 2.5 \mathrm{mM} \cdot \mathrm{L}^{-1}\right.$ each), EasyTaq DNA Polymerase $\left(0.15 \mu \mathrm{L}, 5 \mathrm{U} \cdot \mu \mathrm{L}^{-1}\right)$, and $10 \times$ PCR buffer $\left(2.5 \mu \mathrm{L}, 25 \mathrm{uM} \cdot \mathrm{L}^{-1}\right)$. A Biometra thermal cycler (Gottingen, Germany) with the following given procedure: an initial denaturation $\left(95^{\circ} \mathrm{C}, 5 \mathrm{~min}\right)$, 35 cycles consisting of denaturation $\left(94^{\circ} \mathrm{C}, 15 \mathrm{~s}\right)$, annealing $\left(54^{\circ} \mathrm{C}, 15 \mathrm{~s}\right)$ and extension $\left(72^{\circ} \mathrm{C}, 15 \mathrm{~s}\right)$, and a final extension $\left(72^{\circ} \mathrm{C}, 3 \mathrm{~min}\right)$, was employed for PCR amplification. PCR products were preserved at $4^{\circ} \mathrm{C}$. After agarose gel electrophoresis, the PCR products were sequenced by Shanghai Majorbio Bio-Pharm Technology Co., Ltd. All original sequences were then revised by DNASTAR software (DNASTAR, Madison, WI, USA). One 12S rRNA sequence of Platyrhina hyugaensis Iwatsuki, Miyamoto et Nakaya, 2011 (LC277746) downloaded from NCBI was included in phylogenetic tree study. Anoxypristis cuspidata (Latham, 1794) (KP233202) was chosen as the out-group to root the tree. MEGA 5.0 (Tamura et al. 2011) was used to construct the neighbor-joining (NJ) tree under the Kimura 2-parameter (K2P) model.

\section{RESULTS}

The general morphological features of Platyrhina sinensis are shown in Fig. 1 and Table 1. The most significant character distinguishing this species from others was there were two rows of hooked thorns on middorsum of tail (vs. only one row of hooked thorns on middorsum of tail in P. tangi and P. hyugaensis) (Iwatsuki et al. 2011). Thorns on orbital, nape and scapular regions were not encircled by light yellow or white pigment, which was also different in P. tangi. The detailed counts and measurements of $P$. sinensis were listed in Table 1, which verified the identification of this species in the north of East China Sea.

The neighbor-joining phylogenetic tree is shown in Fig. 2. Specimens of $P$. sinensis in the presently reported study clustered in a group, and those of $P$. tangi and $P$. hyugaensis clustered in another two groups, respectively. Groups of all species including A. cuspidata were well defined based on the distance of the $12 \mathrm{~S}$ rRNA sequence. The genetic distance of the $12 \mathrm{~S}$ rRNA sequence within $P$. sinensis group was only $0.71 \%$, and the mean distance between $P$. sinensis and other two Platyrhina species (P. tangi and P. hyugaensis) was up to $6.01 \%$ and $7.71 \%$, respectively. The interspecific distance was about 8.5-10.6 times larger than intraspecific distance. Together, both the morphological and genetic analysis strongly supported the validity of $P$. sinensis as a new record in Zhoushan.

\section{DISCUSSION}

Although Platyrhina sinensis has little economic value, it shows significance from the aspect of ichthyofaunal conservation and overall fish diversity. The globe is heating up now with warmer lands and oceans than when record keeping began in 1880, and temperatures are still ticking upward (Brander et al. 2003). In response to climate change, long-term trends and variations in abundances and distribution of many marine fish have been observed over the past few years, such as cod, flatfish, salmonids, and so on (Drinkwater 2005, Farrell 2009, Hermant et al. 2010). The previous report showed that $P$. sinensis mainly existed in the Taiwan Strait and the South China Sea (Iwatsuki et al. 2011) and no P. sinensis has ever been collected from other sea areas in China (Iwatsuki et al. 2011). In this study, nine $P$. sinensis individuals were collected from 
Zhoushan. This paper extends the distribution range of this species into the north of East China Sea and represents the northernmost record of $P$. sinensis in China. Our findings indicate that global warming might prompt some $P$. sinensis individuals to migrate northward from its southern habitat like other fishes mentioned above. Attention should be paid to the new region fish species including $P$. sinensis expanded to because their appearance might indicate climatic change, which may make a big difference for local fishery production and fish diversity.

\section{ACKNOWLEDGEMENTS}

Mr Minguang He contributed much to the specimen collection. This work was supported by the National Natural Science Foundation of China (41776171), National Programme on Global Change and Air-Sea Interaction (GASI-02-PAC-YDaut/sum), National Infrastructure of Fishery Germplasm Resources, and Public Science and Technology Research Funds Projects of Ocean (201405010). There are no conflicts of interest and authors are solely responsible for the contents and writing of this paper.

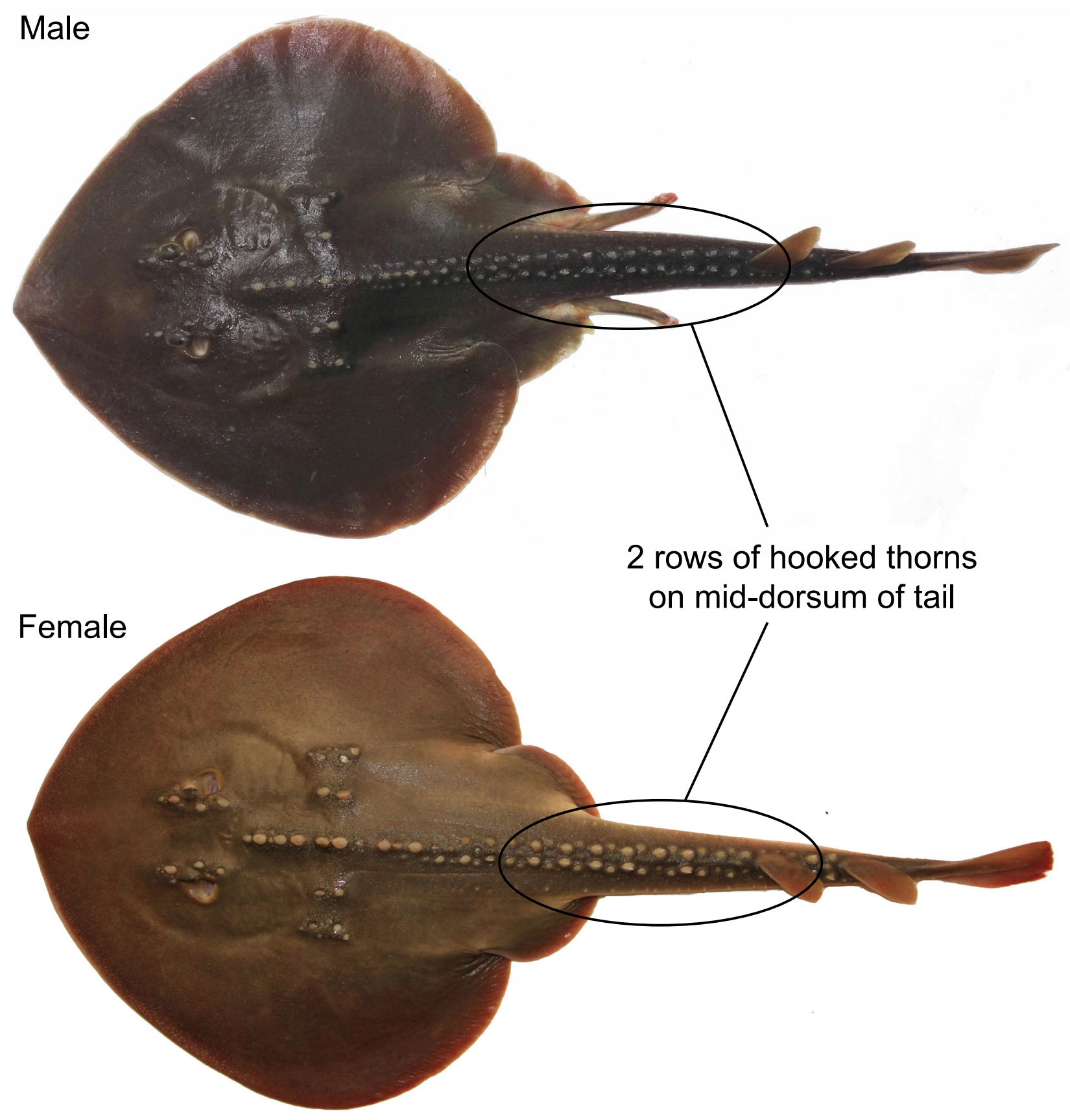

Fig. 1. Dorsal (upper) views of Platyrhina sinensis from Zhoushan, China 
Table 1

Comparative counts and measurements of Platyrhina sinensis and other Platyrhina species from Zhoushan, China

\begin{tabular}{|c|c|c|c|c|}
\hline \multirow{3}{*}{ Character } & \multicolumn{4}{|c|}{ Species } \\
\hline & \multicolumn{2}{|c|}{ P. sinensis $(n=9)$} & \multicolumn{2}{|c|}{ P. tangi $(n=2)$} \\
\hline & Range & Mean \pm SD & Range & Mean \pm SD \\
\hline Total length $[\mathrm{mm}]$ & $210-438$ & & $316-423$ & \\
\hline Number of hooked thorns rows on mid-dorsum of tail & \multicolumn{2}{|c|}{2} & \multicolumn{2}{|c|}{1} \\
\hline Disc length & $45.24-52.17$ & $49.23 \pm 1.75$ & $43.59-51.45$ & $47.52 \pm 2.38$ \\
\hline Disc width & $45.69-55.48$ & $51.85 \pm 2.31$ & $44.98-51.49$ & $48.34 \pm 3.21$ \\
\hline Body depth & $7.08-8.24$ & $7.31 \pm 0.84$ & $5.26-7.01$ & $6.14 \pm 0.52$ \\
\hline Snout to maximum disc width & $39.36-42.19$ & $42.12 \pm 1.24$ & $36.58-41.29$ & $38.94 \pm 2.96$ \\
\hline Head length & $28.31-29.96$ & $29.16 \pm 0.56$ & $21.68-25.86$ & $23.77 \pm 1.08$ \\
\hline Snout to cloaca & $43.58-45.02$ & $44.29 \pm 0.21$ & $39.66-44.81$ & $42.24 \pm 1.09$ \\
\hline Pre-oral length of snout & $15.02-18.43$ & $17.01 \pm 0.42$ & $11.52-12.67$ & $12.10 \pm 0.22$ \\
\hline Pre-orbital length of snout & $15.23-18.66$ & $16.45 \pm 0.33$ & $11.89-13.21$ & $12.55 \pm 0.11$ \\
\hline Prenarial length of snout & $11.09-12.57$ & $12.25 \pm 0.14$ & $9.65-12.04$ & $10.85 \pm 0.48$ \\
\hline Orbit diameter & $3.84-4.97$ & $4.42 \pm 0.26$ & $3.70-4.56$ & $4.13 \pm 0.32$ \\
\hline Eye diameter & $2.10-3.02$ & $2.45 \pm 0.12$ & $2.52-3.01$ & $2.77 \pm 0.54$ \\
\hline Spiracle length & $2.11-2.98$ & $2.56 \pm 0.21$ & $2.11-3.58$ & $2.85 \pm 0.87$ \\
\hline Interorbital width & $5.89-7.02$ & $6.45 \pm 0.43$ & $4.99-6.02$ & $5.51 \pm 0.45$ \\
\hline Inter-spiraclar width & $6.97-7.76$ & $7.59 \pm 0.31$ & $6.34-7.28$ & $6.81 \pm 0.58$ \\
\hline Internarial width & $3.04-3.92$ & $3.52 \pm 0.19$ & $2.41-3.83()$ & $3.12 \pm 0.49$ \\
\hline Mouth width & $9.06-11.31$ & $10.19 \pm 0.75$ & $8.54-9.37$ & $8.96 \pm 0.87$ \\
\hline Nostril length & $1.88-2.23$ & $2.06 \pm 0.09$ & $1.02-1.96()$ & $0.99 \pm 0.21$ \\
\hline Nasal flap length & $1.71-2.97$ & $2.19 \pm 0.23$ & $0.98-2.06$ & $1.52 \pm 0.17$ \\
\hline Distance across anterior nasal apertures & $7.95-8.87$ & $8.47 \pm 0.11$ & $6.39-7.95()$ & $7.17 \pm 0.44$ \\
\hline Snout to first gill opening & $22.09-22.95$ & $22.52 \pm 0.09$ & $19.74-20.82$ & $20.29 \pm 0.36$ \\
\hline First gill opening width & $1.09-1.23$ & $1.17 \pm 0.05$ & $1.17-1.58()$ & $1.38 \pm 0.29$ \\
\hline Fifth gill opening width & $0.98-1.17$ & $1.08 \pm 0.08$ & $1.01-2.01$ & $1.51 \pm 0.52$ \\
\hline Distance between first gill openings & $16.48-17.67$ & $17.24 \pm 0.12$ & $14.46-15.66$ & $15.06 \pm 0.39$ \\
\hline Distance between fifth gill openings & $10.58-13.11$ & $11.79 \pm 0.56$ & $12.86-13.98$ & $13.4 \pm 0.48$ \\
\hline Pelvic fin length & $14.67-18.84$ & $16.84 \pm 0.87$ & $16.33-18.02$ & $17.18 \pm 0.62$ \\
\hline Posterior base of pelvic fin to first dorsal fin origin & $15.72-24.35$ & $20.46 \pm 2.54$ & $17.84-19.20$ & $18.52 \pm 0.71$ \\
\hline First dorsal fin length & $5.89-6.98$ & $6.45 \pm 0.42$ & $6.46-8.79$ & $7.62 \pm 0.62$ \\
\hline First dorsal fin height & $4.11-5.26$ & $4.69 \pm 0.63$ & $3.28-5.96$ & $4.62 \pm 0.25$ \\
\hline First dorsal fin base length & $3.92-5.41$ & $4.67 \pm 0.29$ & $3.69-4.56$ & $4.13 \pm 0.62$ \\
\hline Inter-dorsal distance & $4.11-5.72$ & $5.06 \pm 0.40$ & $4.73-6.17$ & $5.45 \pm 0.24$ \\
\hline Second dorsal fin length & $7.03-9.18$ & $8.11 \pm 0.83$ & $8.16-9.10$ & $8.63 \pm 0.60$ \\
\hline Second dorsal fin height & $4.21-4.78$ & $4.61 \pm 0.34$ & $4.39-5.46$ & $4.93 \pm 0.94$ \\
\hline Second dorsal fin base length & $3.92-6.85$ & $4.96 \pm 0.48$ & $4.06-4.77$ & $4.42 \pm 0.48$ \\
\hline Snout to first dorsal fin origin & $62.29-69.85$ & $66.15 \pm 2.17$ & $55.49-67.71$ & $61.60 \pm 4.69$ \\
\hline Snout to second dorsal fin origin & $69.96-77.47$ & $73.98 \pm 1.47$ & $72.09-77.93$ & $75.01 \pm 2.88$ \\
\hline Posterior base of second dorsal fin to tip of caudal fin & $16.71-18.91$ & $17.86 \pm 0.29$ & $19.18-23.04$ & $21.11 \pm 1.74$ \\
\hline Caudal fin length (dorsal margin) & $15.51-17.16$ & $16.26 \pm 0.61$ & $16.53-19.21$ & $17.87 \pm 1.45$ \\
\hline Caudal fin length (abdominal margin) & $12.14-15.41$ & $13.57 \pm 0.48$ & $16.99-19.62$ & $18.31 \pm 1.31$ \\
\hline Tail length & $53.45-65.75$ & $58.23 \pm 2.19$ & $55.62-59.03$ & $57.33 \pm 2.93$ \\
\hline Tail width at pelvic axil & $7.75-8.89$ & $8.38 \pm 0.42$ & $6.95-7.87$ & $7.41 \pm 0.66$ \\
\hline Ventral fold width at first dorsal fin origin & $0.45-1.24$ & $0.83 \pm 0.19$ & $0.12-0.97$ & $0.55 \pm 0.10$ \\
\hline Clasper length & $13.65-14.42$ & $13.94 \pm 0.11$ & $12.44-18.09$ & $15.27 \pm 1.32$ \\
\hline
\end{tabular}




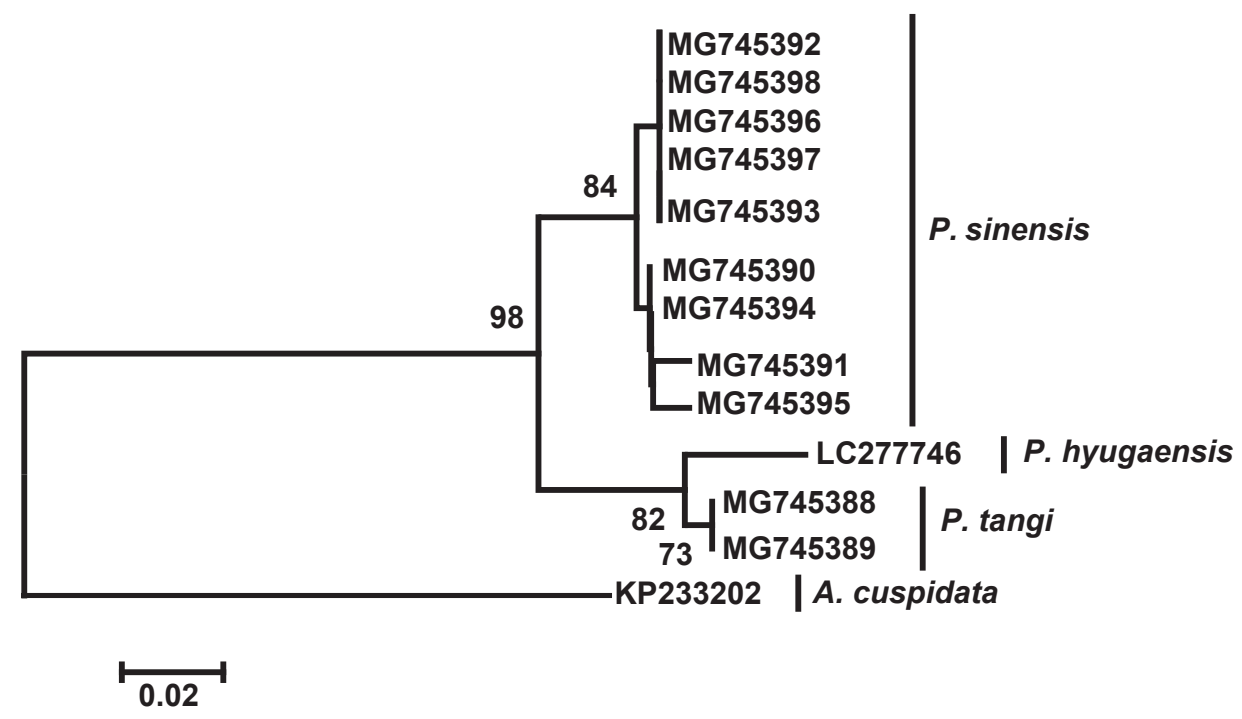

Fig. 2. Phylogenetic tree of three Platyrhina species based on neighbor-joining analysis of $12 \mathrm{~S}$ rRNA sequence; numbers above branches indicate neighbor-joining bootstrap percentages; only bootstrap values of $>70 \%$ are shown in the above NJ tree

\section{REFERENCES}

Bloch M.E., Schneider J.G. 1801. M.E. Blochii, doctoris medicinae berrolinensis, et societatibus literaris multis adscripti, SYSTEMA ICHTHYOLOGIAE ICONIBUS CX ILLUSTRATUM. Post obitum auctoris opus inchoatum absolvit, correxit, interpolavit Jo. Gottlob Schneider, Saxo. Berolini, Sumtibus Austoris Impressum et Bibliopolio Sanderiano Commissum. Berlin, Kingdom of Prussia. [In Latin.] DOI: $10.5962 /$ bhl.title. 5750

Brander K., Blom G., Borges M.F., Erzini K., Henderson G., MacKenzie B.R., Mendes H., Ribeiro J., Santos A.M.P., Toresen R. 2003. Changes in fish distribution in the eastern North Atlantic: Are we seeing a coherent response to changing temperature? ICES Marine Science Symposia, 219 (17): 261-270.

Chen Q.C., Cai Y.Z., Ma X.M. 1997. [Fishes from Nansha Islands to South China coastal waters.] Science Press, Beijing, China. [In Chinese.]

Chu Y.T. 1960. [Cartilaginous fishes of China.] Science Press, Beijing, China. [In Chinese.]

Chu Y.T., Wu H.L. 1984. [Fishes of Fujian Province.] Fujian Science and Technology Press, Fuzhou, China. [In Chinese.]

Compagno L.J.V., Last P.R. 1999. FAO species identification guide for fishery purposes: The living marine resources of the western central Pacific. FAO, Rome.

Compagno L.J.V., Last P.R., Stevens J.D., Alava M.N.R. 2005. Checklist of Philippine Chondrichthyes. CSIRO Marine Laboratories Report No. 243. CSIRO, Canberra, Australia.

Drinkwater K.F. 2005. The response of Atlantic cod (Gadus morhua) to future climate change. ICES Journal of Marine Science 62 (7): 1327-1337. DOI: 10.1016/j.icesjms.2005.05.015
Farrell A.P. 2009. Environment, antecedents and climate change: Lessons from the study of temperature physiology and river migration of salmonids. Journal of Experimental Biology 212 (23): 3771-3780. DOI: 10.1242/jeb.023671

Nakabo T. 2002. Fishes of Japan with pictorial keys to the species. English edition. Tokai University Press, Tokyo, Japan.

Hermant M., Lobry J., Bonhommeau S., Poulard J.-C., Le Pape O. 2010. Impact of warming on abundance and occurrence of flatfish populations in the Bay of Biscay (France). Journal of Sea Research 64 (2): 45 53. DOI: 10.1016/j.seares.2009.07.001

Iwatsuki Y., Miyamoto K., Nakaya K., Zhang J. 2011. A review of the genus Platyrhina (Chondrichthys: Platyrhinidae) from the northwestern Pacific, with descriptions of two new species. Zootaxa 2738 (14): 26-40.

Last P.R., White W.T., Fahmi 2006. Rhinobatos jimbaranensis and $R$. penggali, two new shovelnose rays (Batoidea: Rhinobatidae) from eastern Indonesia. Cybium 30 (3): 261-271.

Miya M., Sato Y., Fukunaga T., Sado T., Poulsen Y., Sato K., Minamoto T., Yamamoto S., Yamanaka H., Araki H., Kondoh M., Iwasaki W. 2015. MiFish, a set of universal PCR primers for metabarcoding environmental DNA from fishes: Detection of more than 230 subtropical marine species. Royal Society Open Science 2 (7): e150088. DOI: 10.1098/ rsos. 150088

Tamura K., Peterson D., Peterson N., Stecher G., Nei M., Kumar S. 2011. MEGA : Molecular evolutionary genetics analysis using maximum likelihood, evolutionary distance, and maximum parsimony methods. Molecular Biology and Evolution 28 (10): 2731-2739. DOI: 10.1093/molbev/msr121 
Tang D.S. 1933. On a new ray (Platyrhina) from Amoy, China. Lingnan Science Journal 12 (4): 561-563.

White W.T., Last P.R. 2016. Platyrhina psomadakisi sp. nov., a new species of fanray (Batoidea: Platyrhinidae) from the Andaman Sea, the first record of this family in the Indian Ocean. Zootaxa 4121 (5): 533-544. DOI: 10.11646/zootaxa.4121.5.3

Zhang C. L., Cheng Q.T., Zhang B.S. 1955. [The investigation report on the fishes of the Bohai Sea and Yellow Sea.] Science Press, Beijing, China. [In Chinese.]
Zhao S.L., Chen J., Yu F.J. 2012. [Study on species composition, distribution and resources of Zhejiang marine fishes.] Journal of Zhejiang Ocean University 31 (1): 1-11. [In Chinese with English abstract.]

Zhao S.L., Xu H.X., Zhong J.S., Chen J. 2016. [Marine Fishes of Zhejiang.] Zhejiang Science and Technology Press, Hangzhou, China. [In Chinese.]

Zhu H.F., Meng Q.W. 2001. [Fauna Sinica, Cyclostomata and Chondrichthyes.] Science Press, Beijing, China. [In Chinese.]

Received: 5 April 2018

Accepted: 5 August 2018

Published electronically: 31 December 2018 